\title{
PRZESTRZENIE KONTESTACJI W TWÓRCZOŚCI BOHUMILA HRABALA, MIRONA BIAŁOSZEWSKIEGO I WOLFGANGA HILBIGA ${ }^{1}$
}

\author{
EMILIA KLEDZIK² \\ (Poznań) \\ Słowa kluczowe: spatial turn, postkolonializm, Bohumil Hrabal, Miron Białoszewski, \\ Wolfgang Hilbig \\ Keywords: spatial turn, postcolonial studies, Bohumil Hrabal, Miron Białoszewski, \\ Wolfgang Hilbig
}

\begin{abstract}
Abstrakt: Emilia Kledzik, PRZESTRZENIE KONTESTACJI W TWÓRCZOŚCI BOHUMILA HRABALA, MIRONA BIAŁOSZEWSKIEGO I WOLFGANGA HILBIGA. „PORÓWNANIA” 11, 2012, Vol. XI, s. 233-246, ISSN 1733-165X. Artykuł referuje stan badań nad przestrzenią w literaturze, poczynając od ustaleń strukturalistów, przez semiotykę, po antropologię i spatial turn. Stawia tezę, że współczesny powrót przestrzeni w badaniach literaturoznawczych jest spowodowany popularnością teorii postkolonialnej. Autorka do dotychczasowych reinterpretacji postkolonialnych w badaniach nad literaturą środkowoeuropejską dołącza grupę tekstów powstałych w lub w odniesieniu do czasów socjalistycznych. Omówione teksty autorstwa Bohumila Hrabala, Mirona Białoszewskiego i Wolfganga Hilbiga przy użyciu stylistyki karnawału kreują różne przestrzenie kontestacji oficjalnego dyskursu o subwersywnym potencjale: knajpę, dworce i bazary oraz świat podziemnego Berlina.
\end{abstract}

Abstract: Emilia Kledzik, THE SPACES OF CONTESTATION IN THE WORKS OF BOHUMIL HRABAL, MIRON BIAŁOSZEWSKI AND WOLFGANG HILBIG. "PORÓWNANIA" 11, 2012, Vol. XI, pp. 233-246, ISSN 1733-165X. The article reports the state of research on the space in literature, starting with the findings of the structuralists, through semiotics, to anthropology and the spatial turn. It argues that the modern return of the space took place due to the popularity of the post-colonial theory in literary studies. The author adds a group of texts created in or in

\footnotetext{
${ }^{1}$ Praca zrealizowana w ramach programu Ministra Nauki i Szkolnictwa Wyższego pod nazwą „Narodowy Program Rozwoju Humanistyki” w latach 2012-2014.

2 Correspondence Address: emilia.kledzik@gmail.com
} 
relation to the socialist' times to the existing post-colonial interpretations of the Central European culture. The texts by Bohumil Hrabal, Miron Białoszewski and Wolfgang Hilbig, discussed using the carnival stylistics, create different spaces of contestation of the official discourse, which posses a subversive potential: a pub, railway stations and bazaars and the underground world of Berlin.

Minęło już ponad 30 lat od pierwszej publikacji tekstu Janusza Sławińskiego pt. Przestrzeń w literaturze: elementarne rozróżnienia i wstępne oczywistoścỉ ${ }^{3}$. Polski strukturalista prorokował $\mathrm{w}$ nim czasy większego zainteresowania przestrzenią w tekście literackim i umieszczał tę kategorię wśród innych - jego zdaniem - analogicznych elementów "struktury" dzieła literackiego, takich jak czas, narrator i sytuacja narracyjna, dialog i dialogowość4. Sławiński zauważał - jak ją nazywał „imperialną" ekspansję przestrzenności w naukach humanistycznych i słusznie stwierdzał, że przestrzeń „nie jest już po prostu jednym z komponentów rzeczywistości przedstawionej, lecz stanowi ośrodek semantyki dzieła i podstawę innych, występujących w nim uporządkowań" ${ }^{5}$. Badacz zawarł w tekście także apel do Kazimierza Bartoszyńskiego, teoretyka literatury reprezentującego inną szkołę metodologiczną ${ }^{6}, \mathrm{w}$ którym konstatował:

To, co Bartoszyński uczynił w swojej ostatniej znakomitej pracy z problematyką czasu w literaturze epickiej, ktoś inny (a może on sam?) w przyszłości z pewnością uczyni z problematyką przestrzeni. Ale wtedy wszyscy będą się już ekscytować całkiem innymi sprawami ${ }^{7}$.

Choć Bartoszyński nigdy postulowanego tekstu nie napisał, trudno jest oprzeć się intuicji, że gdyby to zrobił, jego analiza nie straciłaby na aktualności tak drastycznie, jak stało się to w przypadku tekstu Janusza Sławińskiego. To z semiotyki, tej inspirowanej analizami mitów Claude'a Levi-Straussa, a przede wszystkim tej wypracowanej na uniwersytecie w Tartu, nie zaś z ortodoksyjnego strukturalizmu, narodziło się bowiem popularne $\mathrm{w}$ najnowszych badaniach literaturoznawczych antropologiczne ujęcie przestrzeni. Badania nad nią podążyły właśnie tą pomijaną przez część strukturalistów, a postulowaną przez semiotyków, drogą antropolo-

3 J. Sławiński, Przestrzeń w literaturze: elementarne rozróżnienia i wstępne oczywistości, w: Przestrzeń i literatura. Red. M. Głowiński, A. Okopień-Sławińska. Wrocław 1978. Cytuję za wydaniem zamieszczonym w zbiorze: J. Sławiński, Próby teoretycznoliterackie. Warszawa 1992.

${ }^{4}$ Ibidem, s. 195.

${ }^{5}$ Ibidem, s. 196.

${ }^{6}$ Por. A. Łebkowska, Narracja, w: Kulturowa teoria literatury. Główne pojęcia i problemy. Red. M. P. Markowski, R. Nycz. Kraków 2006, s. 183.

${ }^{7}$ J. Sławiński, op. cit., s. 197. Mowa o tekście K. Bartoszyńskiego pt. Problem konstrukcji czasu w utworach epickich, w: Problemy teorii literatury. Seria 2. Red. H. Markiewicz. Wrocław 1976. 
gicznej lektury międzykulturowej. Przestrzeń w utworze literackim jest - o czym student pierwszego roku filologii polskiej dowiaduje się na kursie poetyki - nie tylko miejscem wydarzeń, ale jednym z podstawowych nośników znaczenia. Obowiązujące normy kulturowe, hierarchie wartości, wyobrażenia zbiorowe dotyczące centrum i marginesów, tego, co własne, i tego, co obce, objawiają się w kreacjach przestrzennych $\mathrm{i} \mathrm{w}$ funkcjonowaniu $\mathrm{w}$ nich podmiotu. $\mathrm{W}$ przestrzeni w literaturze dopełniają się symboliczny i wyobrażony potencjał języka, treści kulturowe (mityczne, archetypiczne, intertekstualne: badania toposów i motywów) i doświadczenia indywidualne.

Alegoryczne i symboliczne budowanie przestrzeni jako projekcji podmiotu mówiącego $\mathrm{w}$ tekście literackim funkcjonowało $\mathrm{w}$ dziewiętnastowiecznych manifestacjach europejskiego podmiotu, który anektował świat przedstawiony, czyniąc z niego ekspresję „„ja”. Dla semiotyków przestrzeń stanowiła projekcję znaczeń kulturowych $\mathrm{w}$ porządek tekstu literackiego. Te dwie perspektywy połączył pochodzący z lat siedemdziesiątych XX wieku projekt Yi-Fu Tuana, który antropologizował przestrzeń przedstawioną $w$ tekście, wskazując jej najważniejsze wektory: wertykalność-horyzontalność, przód-tył oraz prawo-lewo ${ }^{8}$. Od czasów Rolanda Barthesa i Jurija Łotmana rozważania o przestrzeni zbliżały do siebie ujęcia antropologiczne i literaturoznawcze. Także Michel Foucault w słynnym tekście o heterotopiach, pisał o miejscach „wyznaczanych wraz z tworzeniem się społeczeństwa"9, a zatem należących do sfery szeroko pojętej kultury. W stronę nauk społecznych podążyły tezy ponowoczesnego urbanisty Edwarda Soi, przedstawione $\mathrm{w}$ programowej książce pt. Postmodern geographies z 1989 roku $^{10}$. Rozprawa proklamowała przewrót przestrzenny i "uprzestrzennienie narracji historycznej” w odwołaniu do myśli francuskiego marksisty Henry'ego Lefebvre, który w latach siedemdziesiątych XX wieku pisał o społecznym „wytwarzaniu” przestrzeni, odzwierciedlającej podziały społeczne ${ }^{11}$. Nowe otwarcie przestrzenne $\mathrm{w}$ literaturoznawstwie, przede wszystkim w niemieckiej refleksji teoretycznej, nie byłoby natomiast możliwe bez impulsu ze strony studiów postkolonialnych. Mam tu na myśli nie tylko odczarowanie kartografii, sztuki odwzorowywania przestrzeni w służbie konkwistadorów. W obszarze zainteresowania lektury postkolonialnej leży konkretne, istniejące poza tekstem literackim miejsce, pojmowane jako agon, na którym i o który rywalizują żywioły kulturowe. Dwa tomy zbiorowe pt. Spatial turn wydane w 2008 roku: w Niemczech i w Nowym Jorku ${ }^{12}$ skłaniają do posta-

8 Por. Yi-Fu Tuan, Przestrzeń i miejsce. Przeł. A. Morawińska. Warszawa 1987.

${ }^{9}$ M. Foucault, O innych przestrzeniach. Heterotopie. „Teksty Drugie” 2005, nr 6, s. 120.

${ }^{10}$ E. W. Soja, Postmodern geographies. The Reassertion of Space in Critical Social Theory. London 1989

${ }^{11}$ Por. M. C. Franck, Die Literaturwissenschaften und der spatial turn, w: W. Hallet, B. Neumann (Hrsg.), Raum und Bewegung in der Literatur. Die Literaturwissenschaften und der Spatial Turn. Bielefeld 229, s. 58.

12 B. Wharf, S. Arias (red.), The Spatial Turn. Interdisciplinary perspectives. New York 2008; J. Döring, T. Thielmann, Spatial turn: Das Raumparadigma in den Kultur- und Sozialwissenschaften. Bielefeld 2008. 
wienia tezy, że przestrzeń „powraca” przede wszystkim w takim odczytaniu tekstów literackich, w których istotne są fluktuacje dyskursywnej i politycznej władzy. W tym sensie fundacyjnym dla takich postzależnościowych - by użyć terminu Hanny Gosk - odczytań przestrzennych jest wspomniany wykład Michela Foucault, w którym pojawia się definicja heterotopii. Jego obserwacja, że XX wiek jest wiekiem przestrzeni, w odróżnieniu od XIX ogarniętego obsesją historii13, daje się wpisać w kontekst myśli postkolonialnej, która zajmuje się także odkłamywaniem lub/i odkrywaniem polifonicznego kulturowego potencjału miejsc (niegdyś) zawłaszczonych. Ona sama nie istniałaby bez badań nad przestrzenią w tekście literackim: Edward Said pisze wszak o koloniach jako o miejscu obligatoryjnie oddalonym od centrum władzy i dyskursu, a Mary Luise Pratt używa terminu "contact zone" na określenie sfery, w której imperialne spojrzenie napotyka Innego.

Przestrzeń zajmuje ważne miejsce w również pracach niemieckiego slawisty, Karla Schlögla. W jego tekście pt. Spatial turn - nareszcie z tomu W przestrzeni czas czytamy ... ${ }^{14}$ przestrzeń powraca jednak raczej jako inspiracja eseistyczna niż kategoria interpretacyjna. $\mathrm{W}$ niemieckim literaturoznawstwie taki powrót przestrzeni mógł zostać przyjęty z ulgą z powodu wcześniejszego bezdyskusyjnego zdyskredytowania tej kategorii przez ideologię narodowosocjalistyczną ${ }^{15}$. A przecież jeśli dzisiaj uruchamia się kategorię przestrzeni, to zazwyczaj nie odbywa się to $\mathrm{w}$ duchu Bachelardowskiej epifanii, ale "odsłaniania" miejsca jako jednego z podstawowych komponentów tożsamości zbiorowych, które bywa zarówno sceną, jak i bohaterem takich dyskursywnych praktyk, jak orientalizowanie czy mimikra. Sigrid Weigel w programowym tekście o topographical turn, który od spatial turn odróżniać ma jego "graficzny", referencjalny charakter, pisze:

Przestrzeń nie jest tu już powodem ani warunkiem, pod którym lub z którego wydarzenia lub opowiadanie o nich biorą swój początek, zdecydowanie bardziej traktuje się ją samą jako rodzaj tekstu, którego ślady odszyfrowywać trzeba semiotycznie, grammatologicznie lub archeologicznie ${ }^{16}$.

Kontynuatorem myśli Michela Foucault o heterotopiach w duchu antropologicznym jest Marc Augé, z koncepcją „nie-miejsca”, czyli „miejsca antropologicznego, które (...) nie integruje dawnych miejsc"17. Nie taka przestrzeń - parafrazując metaforę Benedicta Andersona - „wyobrażona” jest przedmiotem zainteresowania

${ }^{13}$ M. Foucault, op. cit., s. 117.

${ }^{14}$ K. Schögel, W przestrzeni czas czytamy... O historii cywilizacji i geopolityce. Przeł. Ł. Musiał, I. Drozdowska, Poznań 2009.

${ }_{15}$ Por. M. C. Franck, Die Literaturwissenschaften und der spatial turn, op. cit., s. 63.

${ }^{16} \mathrm{~S}$. Weigel, Zum "tophigraphical turn". Kartographie, Topographie und Raumkonzepte in den Kulturwissenschaften, „KulturPoetik” 2002, nr 2, s. 160.

${ }^{17}$ M. Augé, Od miejsc do nie-miejsc, w: idem, Nie-miejsca. Wprowadzenie do antropologii hipernowoczesności. Warszawa 2010, s. 53. 
lektury postkolonialnej. W niej narodzić się może co najwyżej „samotna indywidualność w drodze, w tymczasowości i efemeryczności"18, nie zaś gęste od kulturowych znaczeń miejsce o subwersywnym potencjale.

Zawiązana w XX wieku nić relacji między podmiotem a kulturowym ustrukturowaniem przestrzeni $\mathrm{w}$ tekście literackim wykazała się więc dużą wytrzymałością, a dziś wraca w licznych odczytaniach postzależnościowych, także w kontekście środkowoeuropejskim. Elżbieta Rybicka, badaczka przeszczepiająca na polski grunt literaturoznawczy termin "geopoetyka", tak pisze o powrocie przestrzeni do dyskursu:

Skoro kultura jest zawsze uwarunkowana i obramowana sytuacyjnie, to przestrzeń (a wraz z nią także czas, okoliczności polityczne i ekonomiczne) stanie się jednym z jej najważniejszych wyznaczników. Nie jest to już oczywiście abstrakcyjna przestrzeń fizyczna, ale przestrzeń doświadczenia kulturowego i egzystencjalnego. $Z$ tego powodu cele, jakie sobie stawiają nowe dyscypliny, są zbieżne - odpowiedzieć na pytania, w jaki sposób przestrzenie i miejsca są przez nas doświadczane i interpretowane, jak kształtują tożsamość jednostkową i zbiorową, płciową i etniczną, jak „upamiętniają" [...] dominującą kulturę ${ }^{19}$.

Takie przestrzenne reinterpretacje literatury $\mathrm{w}$ duchu postkolonialnym dotyczyły w Polsce przede wszystkim tzw. powieści kresowej, literackich obrazów miast o wielokulturowej historii oraz fundacyjnych dla polskiej myśli narodowej tekstów romantycznych ${ }^{20}$. Postulaty, by podobną lekturę odnieść również do (dyskusyjnie) postkolonialnego okresu sowietyzacji Europy Środkowej, pozostały jak dotąd bez literaturoznawczego odzewu. Niniejszy tekst nie ma na celu wypełnienia tej luki, a jedynie prezentację znanych interpretatorom przykładów literackich przestrzeni o sensualnym, niejednorodnym i peryferyjnym charakterze, w których można dostrzec subwersywny potencjał strategii postkolonialnej, nazwanej przez Edwarda Saida „kontrapunktową". Choć w powszechnej praktyce interpretacyjnej przestrzenie te "czyta się" zwykle poza dyskursem władzy-podporządkowania, owe specjalne "nisze", położone w oddaleniu od tego, co oficjalne, roszczą sobie prawo do skontrastowanego ze światem potiomkinowskiej wsi (kolonialnej maskarady?) "autentyzmu”. Wskazana w tytule przestrzeń kontestacji w twórczości Bohumila Hrabala, Mirona Białoszewskiego i Wolfganga Hilbiga jest w założeniu projektem jednocześnie awangardowym i ugruntowanym na żywiole karnawałowym, w znaczeniu, jakie nadaje temu terminowi Michaił Bachtin. U Bohumila Hrabala będzie nią gospoda/knajpa, w której toczy się skarnawalizowany monolog narratorów i bohaterów. U Mirona Białoszewskiego podobny potencjał kryje się w portretach

18 Ibidem.

19 E. Rybicka, Geopoetyka, w: M. P. Markowski, R. Nycz, Kulturowa teoria literatury, op. cit., s. 477.

${ }^{20}$ Por. np. D. Skórczewski, Dlaczego Pawet Huelle napisat "Castorpa”?, "Teksty Drugie” 2006, nr 3; B. Bakuła, Kolonialne i postkolonialne aspekty polskiego dyskursu kresoznawczego [zarys problematyki], "Teksty Drugie" 2006, nr 6; T. Ewertowski, Ahnelli Juliusza Stowackiego - próba odczytania postkolonialnego, w: Stowacki postkolonialny. Red. M. Kuziak. Bydgoszcz 2010. 
bazarów i szlaków kolejowych, zaś dla wschodnioniemieckiego pisarza Wolfganga Hilbiga aktem kontestacji stanie się zejście do piwnic Berlina i życie w jego fundamentach. Te przestrzenie: knajpę, bazar, szlak kolejowy i podziemia miasta łączy gest inscenizacji, doza teatralności i literackiego przerysowania (tak prozatorskiego, jak poetyckiego). Ich kreacja jest szczególnie nacechowana oporem wobec dyskursu oficjalnego, politycznego kodu języka i przestrzeni władzy. To zatem gest nie tylko kulturowy, ale także etyczny. Hrabal, Hilbig i Białoszewski posługują się przestrzennym szyfrem, na który składają się miejsca wykluczone, zakazane, wyklęte, ale też: prastare i rytualne, gdzie panuje karnawałowa atmosfera familiarnego kontaktu. Nie zawsze są to przestrzenie spójne: u Hilbiga przesycona erotyzmem i podświadomymi lękami przestrzeń podziemia może $\mathrm{w}$ niektórych aspektach kontrastować z wesołym miasteczkiem Białoszewskiego i beztroską nudą Hrabalowskich knajp; łączy je jednak zamysł bycia kontrprzestrzeniami dla - by sparafrazować słowa Ryszarda Nycza o futurystach - „rezerwatów, w których władza ludowa zamknęła artystów"21. Ucieczka w codzienność, którą uprawiają - każdy na swój sposób - Hrabal, Białoszewski i Hilblig znajduje swoje przełożenie na kreacje przestrzenne: ich dominującymi atrybutami są: zwykłość, powszedniość, łatwa dostępność i wreszcie - ikoniczność. Podobnie jak założeniem futurystów było „anektowanie" rejonów dotychczas dla sztuki niedostępnych, tak ci literaci promowali swoją podmiotowość aż do granicy teatralności, przesady, performance'u. I tak jak u futurystów, wbrew sztuczności świata realnie istniejącego socjalizmu, zjawia się metoda unaoczniania, cytowania rzeczywistości.

\section{HRABAL I GOSPODA}

Bohumil Hrabal, syn administratora browaru, od najmłodszych lat często odwiedzał knajpy; nic więc dziwnego, że stały się one jednym $\mathrm{z}$ podstawowych miejsc, w jakich toczyć się miały jego literackie monologi. Przedmiotem analizy $\mathrm{w}$ tej części tekstu uczynię wybrane utwory z różnych okresów życia pisarza: opowiadania Śnięte popotudnie z 1963 roku oraz Bar Świat z 1969 roku, w szczególności zaś opublikowany w latach dziewięćdziesiątych esej pt. Czym jest knajpa.

Czeska hospoda, tak nieadekwatnie tłumaczona na język polski, to w twórczości Hrabala przede wszystkim miejsce, gdzie snucie opowieści odwraca porządek zewnętrza:

Knajpa jest (...) miejscem, w którym poprzez ożywioną grę i żywe obrazy można przedstawić to, co nieosiągalne, gdzie dzięki nieświadomości można osiągnąć godne potępienia dostojeństwo, jak również obalić samooskarżenie ${ }^{22}$

${ }^{21}$ Por. R. Nycz, Jezyk modernizmu. Prolegomena historycznoliterackie. Wrocław 1997, s. 47.

22 B. Hrabal, Czym jest knajpa, w: idem, Piękna rupieciarnia. Przeł. J. Stachowski. Wołowiec 2006, s. 147. 
- pisze Hrabal. To świat „prawdziwych”, choć ubranych w teatralny kostium, wartości wspólnotowych, na wskroś demokratyczny i ludyczny, w którym znaczenie tracą wzorce heroiczne:

Bywalec knajpy nie pragnie znaleźć się w innym kraju jako żołnierz, a nawet nie pragnie polec w swoim kraju, nie chce polec nawet w tym mieście, miasteczku, wsi, gdzie jest jego gospoda. Spełnieniem jego życia, gdy już nastanie ten czas, jest śmierć w swojej knajpie ${ }^{23}$.

Chodzenie do knajpy jest dla jego narratorów i bohaterów formą rytuału, który - jak w obrządku karnawałowym - pozwala opuścić na chwilę dotychczasowe ramy życia, jednak bez ich całkowitego podważania. „To miejsce, gdzie toczy się zarówno play, jak i game, zbiorowy teatr, happening" 24 - dopowiada Hrabal. Maskarada, jaką uprawiają bywalcy knajp, dotyczy - jak w Bachtinowskim karnawale - rzeczywistych ról społecznych, ich parodiowania, odgrywania, samowolnego rozdawnictwa. W tle - jak przystało na obrządek quasi-religijny - kryje się subtelny wątek inicjacyjny. Knajpa jest miejscem, gdzie osiąga się społeczną dojrzałość. W Śniętym popotudniu mowa jest o innym rodzaju dorastania: oto młody mężczyzna, choć przebywa w przestrzeni rytualnie zarezerwowanej do celebrowania adolescencji, wyraźnie nie chce ulec woli obecnych w niej starszych. Zaś w surrealistycznym opowiadaniu pt. Bar Świat, choć knajpa staje się areną wydarzeń ostatecznych, tragicznych, przełomowych, wyraziście kontrastujących z jej ludycznym charakterem, stanowi idealne tło dla absurdalnego splotu wydarzeń, monologów i gestów.

„Knajpa jest także miejscem, gdzie mówi się to, czego się nie mówi gdzie indziej" 25 - notuje Hrabal. Ma, podobnie jak karnawał, moc wyzwalania logorei. Mowa ta jest, pozornie nieuporządkowana, systematyczna w niesystematyczności, planowo chaotyczna. Gawęda Hrabalowskiego narratora lub narratorki ma potencjał podważania paradygmatów, nie tylko dlatego, że płynie w miejscach oddalonych od oficjalności, na drugim planie, mówiąc językiem Foucaulta - w heterotopiach: przy krematoriach, przy świniobiciu, w kopalniach, w knajpach. Miejsca te są - rzecz jasna - obciążone kulturowym bagażem, do którego kluczem mogą być toposy - miejsca wspólne - kultury czeskiej26. Oprócz kulturotwórczej roli hospody,

23 Ibidem, s. 151.

24 Ibidem, s. 143.

25 Ibidem, s. 147.

26 Aleksander Kaczorowski $w$ Praskim elementarzu tak pisał o Czechach: „Knajpy spełniały w ich życiu podobną rolę, co u nas kościoły. To knajpa była miejscem powszechnej spowiedzi, to w knajpie śpiewało się starodawne pieśni, to w knajpie przyjmowało się ciało i krew czeskiej ziemi - wieprzowinę z kapustą i ziemniakami i "mleko kozła” z Wielkich Popowic. Świat tych ludzi wydawał się doskonale uporządkowany - nikt nigdzie się nie spieszył, nikt nie marzył o innym życiu, nikt nie wydawał się mieć poczucia, że siedząc tu, nad piwem, coś traci”. A. Kaczorowski, Praski elementarz. 
jaką niewątpliwie miał na uwadze Bohumił Hrabal, warto podkreślić jej marginalną, prowincjonalną, zdecentralizowaną lokalizację, która paradoksalnie daje jednak moc integracji. W tym kontekście sprawdza się termin "trzeciej przestrzeni", wprowadzonego do badań postkolonialnych przez Homiego Bhabhę, a podchwyconego przez jednego z ojców spatial turn w naukach społecznych i humanistycznych, Edwarda Soję, w koncepcjach etycznego podziału przestrzeni27. Homi Bhabha definiuje "trzecią przestrzeń" jako językowy byt abstrakcyjny, w którym reprezentowane są zarówno reguły języka, jak i „swoiste uwikłanie wypowiedzi w strategię performatywną i instytucjonalną"28. Taka jest Hrabalowska hospoda, w której głosy maluczkich i wykluczonych, poprzez śmiech konstruują przestrzeń opozycyjną wobec społecznego „zastania”. W jej roli pojawia się inna "prawda”, stworzona w knajpianym, skarnawalizowanym rytuale ${ }^{29}$. Mistrzem nadającym kształt quasi-autobiograficznej narracji jest sam pisarz w przebraniu ludycznego klauna.

\section{BAZARY I DWORCE MIRONA BIAŁOSZEWSKIEGO}

\section{Czeska monografistka Hrabala, Monika Zgustová, pisała o Hrabalu:}

Jego teksty, które pozostawiał niewykończone, „na pół rozbite”, są podobne do przedmieść praskich z drugiej połowy naszego wieku, gdzie odpada tynk i pojawia się goły mur, szczerbią się cegły, wieczne rusztowanie rdzewieje i robią się dziury, z otwartych paszczy kubłów wychodzą straszydła: stosy śmieci i szmelcu. Literatura

Wołowiec 2001. Cytat za M. Zgustová, Bohumil Hrabal. Przeł. Z. Tarajło-Lipowska. Wrocław 2000, s. 156.

27 Por. E. Soja, Thirdspace: Journeys to Los Angeles and Other Real-and-Imagined Places. Oxford 1996.

${ }^{28}$ H. K. Bhabha, Miejsca kultury. Przeł. T. Dobrogoszcz. Kraków 2010, s. 22

${ }^{29}$ W Praskich jasełkach czytamy takie słowa pana Bedara:

„W każdej restauracji ktoś powiedział coś, o czym się dowiedzieć możecie tylko w uczonych księgach. U Pinkasów na przykład jeden gość płakał w piwo i mówił - prawdziwe wykształcenie oznacza zupełną ruinę. Pod Złotym Tygrysem powiedział jeden radca - z łajna bata nie upleciesz, a jak upleciesz, to z niego nie strzelisz. Na Kalczawce raz powiada harmonista - prawdziwy mężczyzna jest zawsze trochę podpity, troszkę zmarznięty i odrobinę śmierdzi uryną. U Dwóch Babek mówił student okularnik - chłopcy, nowoczesna sztuka to kurze oko, do którego wpadło ziarno jęczmienia, a tego ziarna czepiła się śniedź zbożowa. U Rozkosznych mizerny konduktor rzekł - poczucie własnej niższości zdobi człowieka. Pod Złotą Palmą jeden pan w cwikierze przyznał się - cokolwiek powiem, zaraz temu zaprzeczę. W Tichaku rzekła dozorczyni - ordynarne słowa są aktami strzelistymi przeciw grubiaństwu. Kelnerka Pod Białym Barankiem - w tak ludnym mieście, ja taka samotna. Pod Aniołem oświadczył mleczarz - nowocześni ludzie zaczną chodzić pieszo. Pewna panna U Szenfloków oznajmiła - głębokie przeżycie jest tym samym, co biblioteka uniwersytecka. To dopiero, nie? I w każdej restauracji coś pięknego się powiedziało i wciąż się mówi, prawda?" B. Hrabal, Praskie jasełka. Przeł. H. Gruszczyńska-Dębska, w: idem: Perełka na dnie. Warszawa 2011, s. 206-207. 
pisana przez Hrabala była obrazem tego wszystkiego, co go fascynowało, podwórek praskich pełnych resztek starych materiałów, drutów, śrub, części i złomu, jego teksty były podobne do starych, zniszczonych fabryk z wybitymi oknami i ścianami popisanymi, porysowanymi białą kredą i czarnym sprayem ${ }^{30}$.

Słowa te z powodzeniem można by zastosować jako komentarz do twórczości Mirona Białoszewskiego. „Jego lektura polega na szukaniu pod sałatką Eksperymentu treściwego befsztyka Rzeczywistości" - pointował Stanisław Barańczak ${ }^{31}$. W XX-wiecznej historii literatury polskiej trudno o pisarza równie często posądzanego o zdradę, jak i o absolutną wierność mimesis, także w kontekście etosu pisarza-strażnika pamięci zbiorowej. Obecnie panuje pogląd, że nie o odzwierciedlenie, a o kreację $\mathrm{z}$ jej postmodernistycznym potencjałem tu chodzi, choć jest przecież Białoszewski na wskroś przeniknięty rzeczywistością PRL-u i to ona choćbyśmy w tej poezji chcieli dostrzegać przede wszystkim manifest Niewyrażalnego - zjawia się w pierwszej kolejności, kiedy kleimy połamane, eliptyczne, kalekie meandry jego utworów. Kto wie, może w przyszłości zostanie Białoszewski uznany za kogoś na kształt reportażysty zza żelaznej kurtyny, właśnie za sprawą oryginalnego modelu poetyckiego, tak pomysłowo integrującego elementy poetyki postawangardowej z pisaniem quasi-autobiograficznym i językową oraz krajobrazową materią Polski Ludowej. U Białoszewskiego ułomność, niekompletność to (po linii Leśmiana) atrybuty pełni, sensu. Fascynuje go szum w roli swoistego ornamentu komunikacji, zjawiska pozbawionego ramy racjonalizującej literackie zastosowanie. Szum rozumiany jako - pisze Tomasz Kunz - „wszelkiego rodzaju zakłócenia wewnętrzne i zewnętrzne uniemożliwiające lub utrudniające porozumienie, które same stają się dla poety wartościowym komunikatem"32. Pisanie siebie można też odnieść do pisania rzeczywistości, ujęcia jej w peryferialnym, kiczowatym, nieracjonalnym kształcie, sprzyjającym tekstowo-rzeczywistościowym eksperymentom.

W słynnej Karuzeli z madonnami ikona zunifikowanej tożsamości religijnej i narodowej - Madonna - sprowadzona zostaje do roli rekwizytu w świecie wesołego miasteczka. W jego obrębie wszystko jest „kwiecisto-laurkowe”, przeładowane i w nieustannym, cyklicznym ruchu - sygnalizowanym w tekście wieloma enumeracjami i powtórzeniami. Degradacja symbolu w jarmarcznym świecie nie nosi jednak $\mathrm{u}$ Białoszewskiego znamion profanacji - jest raczej uwzniośleniem tego, co niskie, sakralizowaniem profanum, nobilitacją kiczu. Podobne cechy w geopoetyce Białoszewskiego posiada warszawska Praga i jej nieodłączny element - bazar.

${ }^{30}$ M. Zgustová, Bohumil Hrabal. Przeł. Z. Tarajło-Lipowska. Wrocław 2000, s. 113

31 S. Barańczak, Rzeczywistość Białoszewskiego, w: idem: Poezja i duch Uogólnienia. Wybór esejów 1970-1995. Kraków 1996, s. 286.

32 T. Kunz, "Ja: pole do przepisu”. Miron Białoszewski jako forma istnienia, „Teksty Drugie” 2006, nr 5, s. 39 . 
W wierszu pt. Rozprawa o stolikowych baranach stragan urasta do roli mikrokosmosu, w którym swoje miejsce mają „Babilony”, „Homery”, „Bizancjum”. Metaforą "dyluwium peryferyjne" w odniesieniu do praskiego bazaru tworzy Białoszewski obraz archetypicznego marginesu. Podobnie mityczne atrybuty zostają przypisane budce z piwem w Wołominie, która w wierszu pt. Filozofia Wołomina przeistacza się w stajenkę. Szczególny geopoetyczny potencjał mają w poezji Białoszewskiego wiersze, w których głównym przestrzennym punktem orientacji staje się podłoga: $\mathrm{w}$ utworze pt. Swoboda tajemna jej uwznioślenie odbywa się poprzez metaforę „podłogi obiecanej”, w Podłogo, błogosław - dochodzi do odwrócenia przestrzennego wektora aksjologicznego. Ale kiedy przyjdzie mu opisać obraz o skonwencjonalizowanej estetyce pejzażowej powie "nic nie wiem o tobie / ani o robaku mikropustki / który cię gryzie" 33 [56] (Zielony, więc jest). Nie interesują go usankcjonowane przez artystyczną praktykę sposoby przedstawiania pejzażu, może nawet wątpi $\mathrm{w}$ ich istnienie. $\mathrm{W}$ jego poetyckim projekcie "prawdziwość" przedstawienia mierzy się nie umiejętnością oddania abstrakcyjnego ideału, ale zanurzeniem w dynamice świata, jego zmysłowości, onomatopeiczności, polifonii.

Szczególnym przykładem takich peryferii jest u Białoszewskiego infrastruktura kolejowa. Dworzec, pociąg, środek transportu to $\mathrm{w}$ jego poezji często przestrzenny pretekst, by dać wyraz opisanemu przez Krzysztofa Rutkowskiego „wielkiemu, społecznemu zmieszaniu, wymianie (aktów mowy, idei, zachowań)"34. U Białoszewskiego, komentuje Anna Legeżyńska, sprzęty są podwójnie semiotyzowane, tzn. występują $\mathrm{w}$ roli użytkowej oraz $\mathrm{w}$ roli znaków kultury ${ }^{35}$. Podobnie rzecz ma się przestrzenią w jego tekstach - szczególnie tą, która wykracza poza "mironczarnię". To zewnętrze jest zwykle miejscem spotkania z Obcymi, miejscem podsłuchiwania ich rozmów, miejscem zarażenia, by nie powiedzieć skażenia - ich podmiotowością. Szczególnie silnie obcość ta uwidocznia się w miejscach, w którym ludzie i Miron spotykają się na chwilę, przestrzenie tymczasowe, lecz gęste od komunikacji, do których ludzie zostali „wrzuceni” przez przypadek: historyczny lub transportowy. Taką przestrzenią są warszawskie piwnice $\mathrm{w}$ Pamiętniku $z$ powstania warszawskiego, takie miejsca mnożą się $\mathrm{w}$ pociągach, tramwajach i autobusach. W takich miejscach może Miron bacznie przysłuchiwać się szumom ich mowy i łowić ulubione onomatopeiczne, jarmarczne, trajkoczące pustosłowie. Ów szum pojawia się także w tekście geopoetycznego eseisty, Karla Schlögla o "gorących i zimnych punktach" na mapie miasta:

\footnotetext{
${ }^{33}$ Cytuję za wydaniem: M. Białoszewski, Wiersze. Warszawa 1976. W nawiasie kwadratowym podaję numer strony.

${ }^{34}$ K. Rutkowski, Przeciw [w] literaturze. Esej o „poezji czynnej” Mirona Białoszewskiego i Edwarda Stachury. Bydgoszcz 1987, s. 117, cyt. za Anna Legeżyńska, Dom Mirona Białoszewskiego, w: eadem, Dom i poetycka bezdomność w liryce wspótczesnej. Warszawa 1996, s. 75.

35 Ibidem, s. 79.
} 
W miejscach, będących niczym więcej jak dworcami przeładunkowymi, stacjami przekaźnikowymi dla ruchu ulicznego, miasto nieustannie szumi. Wibruje. Wszędzie wokół pośpiech. Trzeba uważać, aby rzeki ludzi nie odwiodły nas od wytyczonego kierunku i pozwoliły utrzymać kurs. Ludzka rzeka płynie długo, zwalnia być może wtedy dopiero, gdy już nie kursują tramwaje, aby rankiem, bardzo wczesnym, gdy pozostała część miasta budzi się ze snu, znowu zacząć szumieć36.

Miejsca Białoszewskiego są klasycznymi nie-miejscami, w znaczeniu, jakie Schlögel nadaje im za Marcem Augé, pisząc, że w centrach kultury „wszystko przybrało już pewną, jeśli nie ostateczną, formę"37. Na opisywanych przez Mirona bazarach, w pociągach i barach mlecznych „wszystko ciągle płynie, jest prowizoryczna, jest w ruchu lub ruchem”38. Bywa, że Białoszewski tę przypadkowość spotkania odczuwa z charakterystyczną dla siebie neurotyczną wrażliwością - jako wyobcowanie. W wierszu pt. Z kolejowych przypadków czytamy: „w przedziale szarym / takt wybija / siedmiu nie-braci śpiących / przebudziłem się ósmy / obcy" [86]. Bawiąc się wieloznacznością słowa "harmonia”, tworzy pejzaż mentalny podróżnego, który „harmonizuje” ze współpasażerami, na tle rozciągniętego za oknem pociągu na podobieństwo harmonii widnokręgu. Ta „harmonia” w znaczeniu „dopasowania” jest jednak złudna - to jedynie "grająca podobieństwo forma” narzucona Mironowi właśnie poprzez charakter miejsca, w którym przebywa, owego tranzytowego nie-miejsca, tylko chwilowo komponującego ludzi w pozornie spójny oktet pociągowego przedziału. Synchronia wymuszona - jak w lapidarnej, czterowersowej Pociagoli: kiw głów/ kiw butów / kiw kolan [176]. W tym kinetycznym reżimie - mogłoby się wydawać - nie ma miejsca na karnawałową spontaniczność Hrabalowskiej knajpy. A jednak przestrzeń „podróżna” Białoszewskiego naznaczona jest piętnem marginesów, w których rządzi logika komunikacyjnej kakofonii i przypadkowości. Wystarczy sięgnąć do Donosów rzeczywistości i ich pomysłu na poezję, opartego na podsłuchiwaniu kalekich dialogów ludzi, których połączyło przygodne spotkanie w pociągu lub tramwaju. W jednym z nich, pt. Flirt w Otwocku na dworcu pod daszkiem letniego wybiegu poczekalni podróżni spierają się, czy ich spotkanie ma charakter przypadkowy. Ta sama przypadkowość rządzi kompozycją pejzażu w wierszu pt. Ot-zobaczew. Nie jest on jednak - jak mogłoby się wydawać - zestawieniem obrazów widzianych z okna pociągu przejeżdżającego na trasie Otwock-Sochaczew. Sugestię taką podsuwać mógłby tytuł, który podpowiada symultanizm kolażowego ujęcia. Ale obraz, jaki się w nim zjawia, jest niekompletny, lecz nie z powodu ruchu, a z powodu swej peryferyjnej niekompletności. Jego niekonkretność, niejasność, wyrażona - jak to

\footnotetext{
${ }^{36} \mathrm{~K}$. Schlögel, W przestrzeni czas czytamy..., op. cit., s. 286

37 Ibidem.

38 Ibidem, s. 289
} 
zwykle w ustach Mirona-podmiotu - także ułomnością językową („góra kurzu z podbicia podtentegowuje" [154]) powodowana jest przyjęciem przez podmiot perspektywy torów kolejowych, z dala od głównych arterii życia zbiorowego.

\section{PIWNICE WOLFGANGA HILBIGA}

Inną nacechowaną przestrzenią $\mathrm{w}$ twórczości Mirona Białoszewskiego jest piwnica, która, jak pisała Anna Legeżyńska, przejmuje rolę domu-schronu, umacniającego poczucie solidarności i wspólnoty ${ }^{39}$. Odmienną, choć nie radykalnie przeciwstawną rolę pełni ona $\mathrm{w}$ powieściach mało znanego w Polsce wschodnioniemieckiego pisarza, Wolfganga Hilbiga. $W$ jego prozie piwnica jest miejscem bezpiecznym, ale także przestrzenią przeklętą; z Hrabalowską knajpą łączą ją wyraźne ślady skarnawalizowania oraz wyraźne konotacje Freudowskie - postulat by oddać głos temu, co wyparte, stłumione, tak w wymiarze indywidualnym, jak i zbiorowym.

Szczególnie interesująca $w$ kontekście rozważań przestrzennych powieść Hilbiga nosi tytuł "Ja", ukazała się w Niemczech w 1996 roku, a siedem lat później w Polsce. To nie jedyny tekst, należący do tzw. literatury post-enerdowskiej, traktujący o uwikłaniu losów pisarza w karierę agenta Stasi ${ }^{40}$. Tytuł, sugerujący pokrewieństwo losów autora i tekstowego C., kieruje czytelnika na tory lektury autobiograficznej przy wyraźnym wskazaniu, że jest to odczytanie niekompletne. Hilbig nigdy nie współpracował ze Stasi, ba - wielokrotnie naraził się wschodnioniemieckim służbom częstymi wyjazdami na Zachód, aż w latach osiemdziesiątych zdecydował się na ostateczną przeprowadzkę do Norymbergii. "JJ" mówiące, zanim zostaje agentem, jest pisarzem-samoukiem, który, poza pisaniem, para się różnorakimi zawodami, od palacza po sprzątacza, a ostatecznie emigruje na Zachód. Na ścianie berlińskiego pokoju powieściowego alter-ego Hilbiga wisi plakat z prowokacyjnym cytatem z Rimbauda "Ja to kto inny”. Można zatem uznać, że podmiotowość jest tutaj nieustannie kwestionowana, ponieważ nie istnieje nic, co w kulturowo przyjęty sposób mogłoby ją dookreślać: tożsamość, język, przeszłość - doświadczenie, pochodzenie. Także rzeczywistość nie daje podmiotowi trwałego oparcia, jej również przypisuje się atrybuty symulakrum:

Żyliśmy w wewnętrznej rozterce: prowadziliśmy nieprzerwane rozpoznanie, by ustalić, jak dalece rzeczywistość zbliżyła się już do naszych wyobrażeń... nie wolno nam było jednak wierzyć, że one staną się naprawdę rzeczywistością. Nie, nie wierzyliśmy

39 A. Legeżyńska, Dom i poetycka bezdomność..., op. cit., s. 76.

40 Por. B. Burmeister, Unter dem Namen Norma. Stuttgart 1994; CH. Wolf, Co pozostanie (fragm.). Przeł. S. Błaut, „Literatura na Świecie” 1991, nr 7, s. 78-103. 
we własne wyobrażenia, gdyż nasze nieprzerwanie prowadzone rozpoznanie dowodziło - nam samym! że nie ma powodu, aby im wierzyć. [... $]^{41}$.

Zasadniczą funkcją skomplikowanej konstrukcji narracji w twórczości Hilbiga jest chęć „uwolnienia się od własnego ja-robotnika”42. W odróżnieniu od klasycznych powieści autotematycznych w jego utworach istnieje ontologiczna przepaść między ",ja" piszącym, a "ja" opisywanym, a konstruowany przez narratora tekst nie jest tym samym, który usiłują stworzyć jego protagoniści. Hilbig, podobnie jak jego narratorskie "ja", a inaczej niż Bohumil Hrabal, nie chce być robotnikiem, a uratować go przed tym może tylko pisanie. Spójność narratorskiej jaźni niszczy między innymi wypierana przez podmiot seksualność, a wybujały erotyzm w tekstach Hilbiga przybiera funkcję karnawałowej maskarady. Seksualność to instynkt, który, podobnie jak żywioł naturalny zawłaszczający przestrzenie dawnego imperium, przejmuje kontrolę nad rozpadającą się strukturą władzy. Posłannictwem funkcjonariuszy Stasi jest bowiem nie tylko obserwacja, ale również katalogowanie płciowych zachowań jej obiektów. Seksualność staje się przedmiotem pseudonauki, która zdaje niezamierzenie odwracać hierarchię państwowego ratio i cielesności - sugeruje wszak, że jako największy wróg ustroju, płciowość, niepodzielnie dominuje $w$ dyskursie władzy. Podobne znaczenie przypisać można częstemu atrybutowi Hilbigowskiej przestrzeni: rumowisku i wysypisku śmieci - tam, w groteskowy sposób realizuje się niemożliwa w przestrzeni władzy państwowej miłość i seksualność 43 . Np. w opowiadaniu pt. Die Weiber bohater onanizuje się za pomocą pojemnika na śmieci. Onanizm w miejscach publicznych, ekshibicjonizm - jest karnawałową formą zdystansowania się wobec „życia publicznego" w NRD. To manifest przeciwko nobilitowanej przez ustrój "czystości”. Badacze twórczości Hilbiga nazywają go „redukcją do zwierzęcego sedna” [Reduktion auf den animalistischen Kern $]^{44}$, lecz dostrzec $\mathrm{w}$ nim można również elementy Bachtinowskiego groteskowego ciała, charakteryzowanego przez to, co wyparte $z$ oficjalnej prezencji cielesności: metabolizm, trawienie, seksualność. Ambiwalentne porównanie kraju i społeczeństwa do ekskrementów w "Ja", grzybica ciała w Die Weiber, i obsesyjnie powracające elementy ciała to nos, penis, brzuch i usta, podbrzusze kobiety składają się na antytezę obowiązującego prawa. Szczególnie jednak obraz podziemi, kryjących wszelkie zbrodnie popełnione przez system polityczny (inaczej niż w literaturze polskiej, gdzie podziemie często konotuje skojarzenia opozycyjne) z powieści "Ja", nasuwający skojarzenia z kobiecym, łonem, dowodzi subwersywnego charakteru zastosowania elementów karnawałowego ciała.

${ }^{41}$ W. Hilbig, "Ja". Przeł. R. Wojnakowski. Wrocław 2006, s. 36.

42 A. Steiner, Das narrative Selbst. Studien zum Erzählwerk Wolfgang Hilbigs. Bern 2008, s. 61.

${ }^{43}$ S. M. Bordaux, Literatur als Subversion. Eine Untersuchung des Prosawerkes von Wolfgang Hilbig. Göttingen 2000, s. 99.

${ }^{44}$ Ibidem, s.105. 
Teoria postkolonialna zajmuje się między innymi możliwością lub niemożliwością "wyrażenia własnej wielogłosowości" 45 . Podczas gdy czołowa przedstawicielka feminizmu, bell hooks, stanęła w obliczu ciszy ${ }^{46}$, Wolfgang Hilbig, podobnie jak jego środkowoeuropejscy koledzy po piórze, wybrał rozwiązanie przeciwne: logoreję, w której ujawnia się pęknięcie podmiotu wypowiedzi, udowadniając tym samym, że palimpsestowość nie jest własnością wyłącznie postkolonialnej przestrzeni, lecz także postkolonialnego podmiotu.

\section{ZAKOŃCZENIE}

Niełatwo jest złączyć wszystkie trzy przedstawiane wizje literackie wspólnym projektem przestrzeni kontestacji. Interpretacyjną niekoherencję znosi ich subwersywny potencjał. Ów potencjał łączy je przede wszystkim przez wzgląd na niejednoznaczną środkowoeuropejską, postsocjalistyczną wspólnotowość, która czyni wszakże z doświadczenia sowieckiej hegemonii jedną z głównych składowych tożsamości regionu. Niełatwo - także dlatego, że omówione powyżej kontrprzestrzenie są tak intrygująco podobne do tych, które tworzyli pisarze postkolonialni pod rozmaitymi szerokościami geograficznymi. Może więc należałoby mówić o swoistym katalogu miejsc wspólnych, ku którym tym chętniej skłaniają się twórcze umysły, im bardziej dotkliwe staje się oddziaływanie dyskursywnej opresji. Kreowane w ten sposób „miejsca gorące i zimne” nosiłyby znamiona groźnych, wyklętych, marginalnych, powstałych na bazie odwrócenia opozycji przestrzennych z aksjologicznym nacechowaniem: góra-dól, centrum-peryferie. Wymienione powyżej literackie portrety takich miejsc mają - oczywiście - bardzo różne kulturowe umocowania. $Z$ pewnością można by wskazać podobne "przestrzenne szeregi", których interpretacyjny potencjał daje się wyzyskać choćby w perspektywie mitów martyrologicznych lub obszarów pogranicza. Europa Środkowa okazuje się pełna miejsc podatnych na takie komparatystyczne studia z refleksją postkolonialną (postzależnościową) w tle.

45 bell hooks, Margines jako miejsce radykalnego otwarcia. „Literatura na Świecie” 2008, nr 1-2, s. 109.

${ }^{46}$ Ibidem. 